\title{
Synaptic Currents Generating the Inhibitory Surround of Ganglion Cells in the Mammalian Retina
}

\author{
Nicolas Flores-Herr, Dario A. Protti, and Heinz Wässle \\ Neuroanatomische Abteilung, Max-Planck-Institut für Hirnforschung, D-60528 Frankfurt am Main, Germany
}

The receptive field (RF) of retinal ganglion cells (RGCs) consists of an excitatory central region, the RF center, and an inhibitory peripheral region, the RF surround. It is still unknown in detail which inhibitory interneurons (horizontal or amacrine cells) and which inhibitory circuits (presynaptic or postsynaptic) generate the RF surround.

To study surround inhibition, light-evoked whole-cell currents were recorded from $\mathrm{RGCs}$ of the isolated, intact rabbit retina. The RFs were stimulated with light or dark spots of increasing diameters and with annular light stimuli.

Direct inhibitory currents could be isolated by voltage clamping ganglion cells close to the $\mathrm{Na}^{+} / \mathrm{K}^{+}$reversal potential. They mostly represent an input from GABAergic amacrine cells that contribute to the inhibitory surround of ganglion cells. This direct inhibitory input and its physiological function were also investigated by recording light-evoked action potentials of RGCs in the current-clamp mode and by changing the intracellular $\mathrm{Cl}^{-}$concentration.

The excitatory input of the ganglion cells could be isolated by voltage clamping ganglion cells at the $\mathrm{Cl}^{-}$reversal potential. Large light spots and annular light stimuli caused a strong attenuation of the excitatory input. Both $\mathrm{GABA}_{\mathrm{A}}$ receptors and $\mathrm{GABA}_{C}$ receptors contributed to this inhibition, and picrotoxinin was able to completely block it.

Together, these results show that the RF surround of retinal ganglion cells is mediated by a combination of direct inhibitory synapses and presynaptic surround inhibition.

Key words: rabbit retina; receptive field; surround inhibition; patch-clamp recording; GABA; glycine
In the vertebrate retina, the direct pathway for light-evoked signals involves photoreceptors synapsing onto bipolar cells, which in turn are connected to ganglion cells. Lateral interactions from horizontal cells and amacrine cells can modulate the light signal in the following ways.

In the outer plexiform layer (OPL), at the photoreceptor-tobipolar cell synapse, horizontal cells may exert an inhibitory action through feedback onto the photoreceptors, or by feeding forward onto the dendrites of bipolar cells (for review, see Piccolino, 1995; Sterling et al., 1995).

In the inner plexiform layer (IPL), bipolar cell axons receive many conventional synapses from amacrine cells, in which they express different combinations of $\mathrm{GABA}_{\mathrm{A}}, \mathrm{GABA}_{\mathrm{C}}$, and glycine receptors (Lukasiewicz and Wong, 1997; Euler and Wässle, 1998; Koulen et al., 1998a). Ganglion cell dendrites also express multiple $\mathrm{GABA}_{\mathrm{A}}, \mathrm{GABA}_{\mathrm{B}}$, and glycine receptors but no $\mathrm{GABA}_{\mathrm{C}}$ receptors (for review, see Feigenspan and Bormann, 1998; Wässle et al., 1998). The multiplicity of synapses and receptors as well as the many different types of amacrine cells (Vaney, 1990; MacNeil and Masland, 1998) suggest multiple pathways for both the feedback inhibition from amacrine cells onto bipolar cell axons and the feedforward inhibition onto ganglion cells.

Many physiological studies, mainly of nonmammalian retinas, have demonstrated lateral or surround inhibition in both the OPL and the IPL (for review, see Cook et al., 1997, 1998; Roska et al.,

\footnotetext{
Received Nov. 27, 2000; revised April 9, 2001; accepted April 10, 2001.

We thank B. Sinke for excellent technical assistance, I. Odenthal for typing the manuscript, and Dr. Brendan O'Brien for critically reading and improving the English text.

Correspondence should be addressed to Dr. Heinz Wässle, Max-Planck-Institut für Hirnforschung, Neuroanatomische Abteilung, Deutschordenstrasse 46, D-60528 Frankfurt am Main, Germany. E-mail: waessle@mpih-frankfurt.mpg.de.

Copyright (C) 2001 Society for Neuroscience $0270-6474 / 01 / 214852-12 \$ 15.00 / 0$
}

2000; Roska and Werblin, 2001). It has been suggested that sustained inhibition is mediated through the horizontal cell action, whereas transient inhibition and more complex operations such as direction selectivity are generated by amacrine cells in the IPL (Werblin, 1991).

In the mammalian retina, lateral inhibitory interactions are well established; however, the precise synaptic mechanisms still need to be elaborated (Kuffler, 1953; Enroth-Cugell and Lennie, 1975; Caldwell et al., 1978; Enroth-Cugell and Jakiela, 1980; Merwine et al., 1995). The contribution of horizontal cells to surround inhibition has been demonstrated by current injections into horizontal cells that antagonized the center light responses of rabbit retinal ganglion cells (Mangel and Miller, 1987; Mangel, 1991). Recent patch-clamp recordings from bipolar cells in a rat retinal slice preparation showed that GABAergic feedback from amacrine cells onto bipolar cells also contributes to surround inhibition (Protti and Llano, 1998; Hartveit, 1999; Euler and Masland, 2000). The involvement of amacrine cells in the ganglion cell surround is further supported by two recent reports showing that tetrodotoxin (TTX) partially blocks the surround measured in retinal ganglion cells (Demb et al., 1999; Taylor, 1999). Lightevoked excitation and inhibition was also observed in retinal ganglion cells with sharp electrodes (Freed and Nelson, 1994) and with patch-clamp electrodes (Rörig and Grantyn, 1993; Protti et al., 1997; Cohen, 1998). However, the spatial profile of the excitatory and inhibitory synaptic input that generates the receptive field was not measured in these studies.

In the present paper, we performed whole-cell recordings from ganglion cells in the isolated, intact rabbit retina (Taylor and Wässle, 1995; Peters and Masland, 1996). We measured the responses of ganglion cells to light spots of increasing diameters projected into the receptive field center (RFC) and thus defined 
area-response functions (Barlow et al., 1957). By applying different holding potentials and measuring the reversal potentials of light-evoked currents, we could dissect excitatory and inhibitory light-driven currents. Thus, it was possible to separate direct inhibitory effects on the ganglion cells from those occurring presynaptically. We applied specific antagonists to $\mathrm{GABA}_{\mathrm{A}}$, $\mathrm{GABA}_{C}$, and glycine receptors to find out what type of receptors are essential for lateral inhibition.

\section{MATERIALS AND METHODS}

Pigmented rabbits of $\sim 2-2.5 \mathrm{~kg}$ were dark adapted for $>3 \mathrm{hr}$ before the experiments, and all subsequent procedures were performed using infrared illumination $(900 \mathrm{~nm})$ to minimize bleaching. The animals were anesthetized by an intramuscular injection of Ketanest and Rompun and subsequently killed by an intravenous injection of Nembutal (sodium pentobarbital). Immediately afterward, one eye was removed, in accordance with guidelines for animal experiments issued by the Federal Republic of Germany (Tierschutzgesetz).

The retina was dissected free from the sclera and the pigment epithelium in a Petri dish perfused with Ames medium (Sigma-Aldrich, Taufkirchen, Germany). A piece was cut out from the central retina, placed photoreceptor side down into the recording chamber, and maintained at $35^{\circ} \mathrm{C}$ in continuously perfused oxygenated Ames medium. Robust light responses could be recorded for up to $8 \mathrm{hr}$ after isolation.

The recording chamber was placed on the fixed stage of an upright microscope (ACM; Zeiss, Oberkochen, Germany), and a water immersion objective was used $(40 / 0.75 \mathrm{~W})$ to observe the electrode and the ganglion cells. The microscope was equipped with infrared $(900 \mathrm{~nm})$ differential interference contrast optics.

Patch-clamp recordings were performed from cells in the ganglion cell layer that had been exposed previously by microdissection of the overlying inner limiting membrane and Müller cell end feet. Details of the patch-clamp recordings have been described by Taylor and Wässle (1995). Briefly, the electrodes had resistances between 5 and $10 \mathrm{M} \Omega$ and were filled with a Cs-gluconate solution having the following composition (in mM): $100 \mathrm{Cs}-\mathrm{Glu}, 0.5 \mathrm{MgCl}_{2}, 10 \mathrm{Na}$-HEPES, 5 EGTA, 0.5 $\mathrm{CaCl}_{2}, 5$ TBA-Cl, $3 \mathrm{Mg}$-ATP, and $0.5 \mathrm{Na}-\mathrm{GTP}$. To block voltage-gated $\mathrm{Na}^{+}$currents, the intracellular $\mathrm{Na}^{+}$channel blocker QX-314 (5 mM) was included in the internal solution. In the experiment illustrated in Figure $6 A$, the electrode was filled with a $\mathrm{K}$-gluconate solution (in mM: 130 KGlu, $4 \mathrm{KCl}, 2 \mathrm{NaCl}, 1 \mathrm{CaCl}_{2}, 10 \mathrm{Na}$-HEPES, 10 EGTA, $4 \mathrm{Mg}$-ATP, and $0.3 \mathrm{NaGTP}$ ) and in the experiment illustrated in Figure $6 \mathrm{~B}$ with a K-chloride solution (in mM: $137 \mathrm{KCl}, 4 \mathrm{NaCl}, 1 \mathrm{CaCl}_{2}, 10 \mathrm{Na}-\mathrm{HEPES}$, 10 EGTA, $4 \mathrm{Mg}$-ATP, and $0.3 \mathrm{NaGTP}$ ). Neurobiotin (Linaris $\mathrm{GmbH}$, Bettingen, Germany) was also added to the internal solution at final concentrations ranging from 0.1 to $0.5 \%$. Conventional histological procedures were performed after the recordings to reveal the morphology of the recorded cells (Vaney, 1992). The cells were drawn directly from the microscope with the aid of a Zeiss drawing apparatus at a final magnification of $1000 \times$ (using a $100 \times$ oil immersion objective). The level of stratification of their dendrites was measured using Nomarski optics by reading the $z$-axis of the microscope. The distance from the cell body (largest cross-section) to the dendritic plexus was thus measured. Patchclamp recordings were made using an EPC-9 patch-clamp amplifier (Heka Electronik, Landau, Germany). Signals were digitized at a frequency at least twice the filter cutoff frequency. Signals were filtered using the built-in eight-pole Bessel filter in the EPC-9 amplifier. Filter cutoff frequencies are quoted as the $-3 \mathrm{~dB}$ attenuation frequency. Unless otherwise noted, filter cutoff frequencies were $2.5 \mathrm{kHz}$. Voltages are given after correction for liquids junction potentials (approximately -15 $\mathrm{mV}$ ) (Neher, 1992). Series resistances ranged from 15 to $40 \mathrm{M} \Omega$ and were left uncompensated in most of the recordings. Drugs were added to the Ames medium and bath applied. Ames medium, strychnine, bicuculline, picrotoxinin, and TTX were all purchased from Sigma-Aldrich.

Visual stimuli were generated on a color Macintosh computer monitor (maximum luminance of $\sim 70 \mathrm{~cd} / \mathrm{m}^{2}$; Apple Computers, Cupertino, CA), and they were imaged through the microscope condenser onto the photoreceptors. The point spread function (width at half-height) including the optical system and the retina was $50 \mu \mathrm{m}$ (Taylor and Wässle, 1995). All stimuli were achromatic, and the stimulus intensity was varied by neutral density filters. The maximum retinal illuminance (corresponding to $70 \mathrm{~cd} / \mathrm{m}^{2}$ at the monitor) was $0.7 \mathrm{~cd} / \mathrm{m}^{2}$. This was $\sim 6 \log$ units above the absolute threshold of the dark-adapted in vitro retina and represents mesopic light conditions. At the start, the center of the light stimulus was aligned with the soma of the cell. After mapping the receptive field center with a small spot, the light stimuli were centered at the peak of sensitivity.

The cells were sampled from the visual streak area and were classified according to their light responses into ON, ON-OFF, and Off center ganglion cells. ON center cells were stimulated with light spots, and Off center cells were stimulated with dark spots.

\section{RESULTS}

A total of 105 ganglion cells were studied. Three criteria were applied to verify that the recordings were from ganglion cells and not from displaced amacrine cells (Taylor and Wässle, 1995; Peters and Masland, 1996): (1) the size and shape of the cell body, (2) the presence of a large voltage-dependent $\mathrm{Na}^{+}$current, and (3) the recovery of the dendritic tree after injection of Neurobiotin, which was possible in approximately half of the cells. $\mathrm{Na}^{+}$ currents could be recorded only immediately after breaking into the cells, before they were blocked by QX-314. The dendritic architecture of ganglion cells imposes a lack of voltage control throughout the cell (Velte and Miller, 1996). To minimize that error, all recorded cells were located close to the visual streak, in which dendritic fields are generally smaller than $300 \mu \mathrm{m}$. Cells were first classified by small spot mapping into ON center ( $n=$ $50)$, Off center $(n=32)$, and ON-Off center $(n=23)$ ganglion cells (Amthor et al., 1989a,b). Their RFCs were defined, and area-response functions were measured (Taylor and Wässle, 1995).

After the experiments, the dendritic morphology of the recorded cells was studied in retinal whole mounts. The retinas were not dehydrated; hence, it was possible to reliably define the level of stratification of their dendrites within the IPL. The dendritic trees of four of the nine ganglion cells, from which physiological recordings are presented below, are shown in Figure 1. The ganglion cell in Figure $1 A$ was recorded in the center of the visual streak as an ON center cell. It has the typical morphology of an $\alpha$ ganglion cell (Peichl et al., 1987; Amthor et al., 1989a) and stratifies in the inner IPL (depth of dendritic stratification, 8 $\mu \mathrm{m})$. The ganglion cell in Figure $1 B$ has a $\delta$-like morphology $(\mathrm{Pu}$ et al., 1990, their Fig. 2E). It was recorded as an Off center cell $800 \mu \mathrm{m}$ ventral from the center of the streak and stratifies in the outer IPL (depth of dendritic stratification, $17 \mu \mathrm{m}$ ). The ganglion cell in Figure $1 C$ has the typical morphology of bistratified ON-OFF direction-selective (DS) ganglion cells (Amthor et al., 1989b; Vaney, 1994). It was recorded as an ON-OFF ganglion cell at $\sim 200 \mu \mathrm{m}$ ventral from the center of the streak, and its dendritic tree is bistratified (depth of dendritic stratification, 8 and $17 \mu \mathrm{m})$. The ganglion cell in Figure $1 D$ was recorded as an ON center ganglion cell at a distance of $1.2 \mathrm{~mm}$ ventral from the center of the visual streak and stratifies in the inner IPL (depth of dendritic stratification, $9 \mu \mathrm{m}$ ). Cells of comparable appearance have been recorded as sluggish concentric cells by Amthor et al. (1989a, their Fig. 12).

\section{Area-response functions of ganglion cells}

There are many types of ganglion cells with distinct morphology, light response waveform, sensitivity, and synaptic inputs in the rabbit retina. It is difficult during patch-clamp recordings from the ganglion cells of the in vitro retina to completely characterize all spatial, temporal, and pharmacological parameters of the cells and record from a sufficiently large sample of all of the cell types. To standardize the response profiles of the cells as much as possible, we applied a rather "simple" stimulus, that is light spots of increasing diameters, and thus measured area-response func- 
Figure 1. Drawings of four ganglion cells from whole-mounted rabbit retinas, viewed from the ganglion cell side. The cells were filled with Neurobiotin during patch-clamp recordings. The axons are indicated by the arrows, and the horizontal axis is parallel to the visual streak. $A, \alpha$ ganglion cell from the center of the streak. Recordings from this cell are shown in Figure 6. $B, \delta$-Like ganglion cell from an eccentricity (distance from the center of the streak) of 800 $\mu \mathrm{m}$. Recordings from this cell are shown in Figure 8. C, Bistratified ON-OFF directionselective ganglion cell. The solid dendrites stratify in the inner IPL, and the dotted dendrites branch $9 \mu \mathrm{m}$ farther, toward the outer IPL. The cell was from an eccentricity of 200 $\mu \mathrm{m}$. $D$, Sluggish concentric ganglion cell from an eccentricity of $1.2 \mathrm{~mm}$. Recordings from this cell are shown in Figures $2 A$ and 5. Scale bar, $100 \mu \mathrm{m}$.

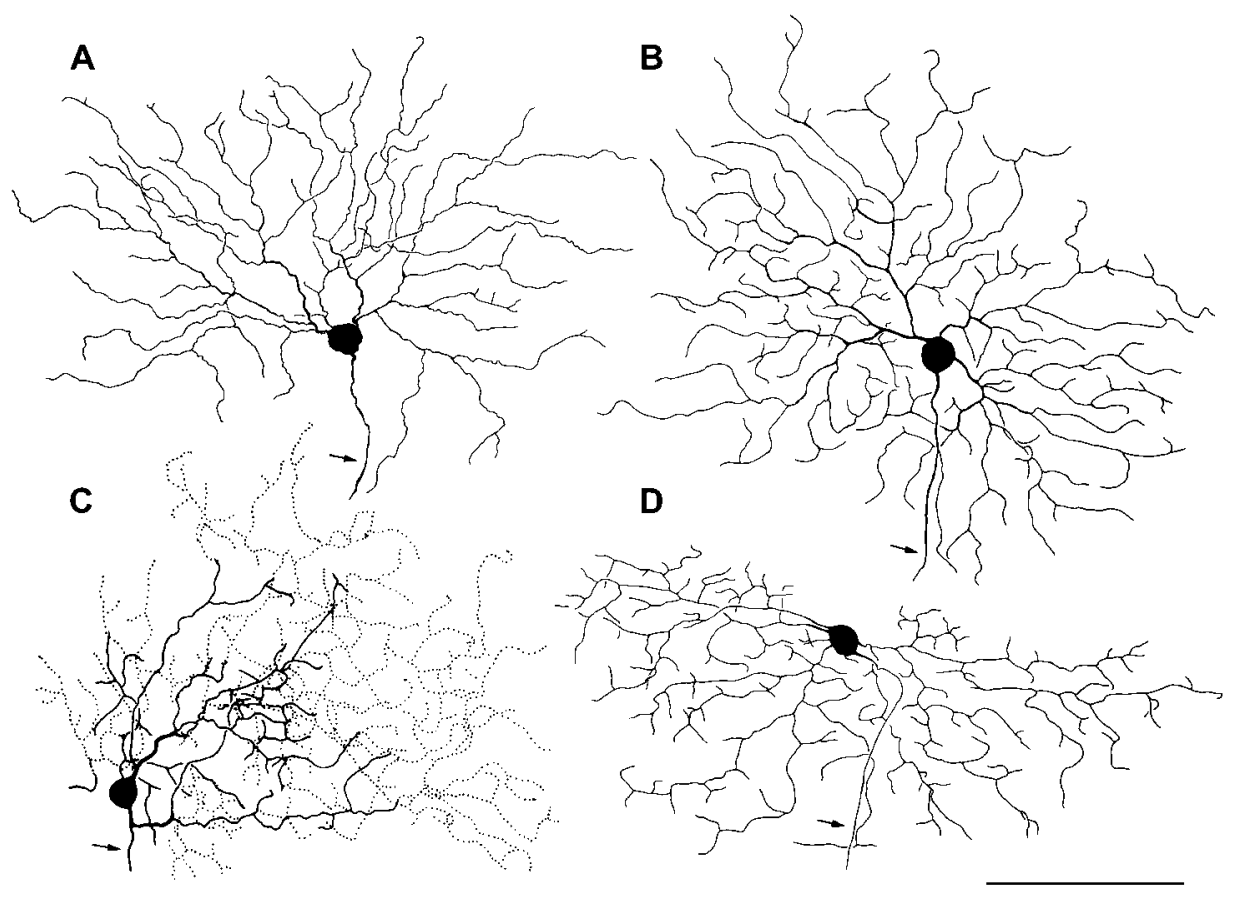

tions. In most instances, we measured the total response (charge) elicited by such light stimuli and did not analyze the temporal differences in response kinetics between excitation and inhibition. Such an integration of the light responses almost certainly obscures important details of the inhibitory interactions; however, because surround effects were qualitatively similar among the different ganglion cell classes of the rabbit (Merwine et al., 1995), we feel justified to pool the data from different cell classes.

Figure $2 A$ shows the light-evoked currents of an $\mathrm{ON}$ center ganglion cell that was voltage clamped at $V_{\mathrm{H}}$ of $-75 \mathrm{mV}$. The morphology of the cell is shown in Figure $1 D$ and is comparable with the sluggish concentric cells described by Amthor et al. (1989a). Light spots of increasing diameter were projected every $2 \mathrm{sec}$ for a duration of $0.4 \mathrm{sec}$ into the RFC of this cell. Stimulation with small spots elicited transient inward currents at light ON. When stimulated with large spots, an additional inward current at light OFF appeared. At the chosen holding potential, the currents represent a mixture of cationic $\left(\mathrm{Na}^{+} / \mathrm{K}^{+}\right)$and anionic $\left(\mathrm{Cl}^{-}\right)$currents. The currents are small for small light spots, they peak for spot diameters of $\sim 200 \mu \mathrm{m}$, and are small again for large spots. Recordings from a representative OFF ganglion cell are shown in Figure $2 B$. The cell was stimulated with dark spots and gave more sustained light responses when the dark spot was switched ON.

The light-evoked currents were quantified, and area-response functions were plotted for the peak currents, for the sustained component of the current, and for the total charge flowing into the cell (Fig. 2C,D). The normalized area-response functions for all three measurements are similar: they increase sharply for spot sizes up to $200 \mu \mathrm{m}$ in diameter, at which they exhibit a sharp peak and decrease continuously for larger spot sizes. The decrease in current amplitude for larger spots is the sign of lateral inhibition. Were there no inhibitory influences, the responses would follow Ricco's law and would not decrease for larger spot sizes (Hurvich and Jameson, 1966). There is an indication in Figure $2 C$ that the transient peak is less susceptible to the increasing inhibition than the sustained component of the light response: apparently inhi- bition lags behind the excitation. This experiment clearly demonstrates that there is lateral inhibition reducing the response of the ganglion cells to large spots, but it does not define where this inhibition occurs: in the network before the ganglion cell (for instance in the OPL) or through direct inhibitory synapses onto the ganglion cell.

\section{Reversal potentials of light-driven responses}

We analyzed the excitatory and inhibitory components of the area-response functions by measuring the reversal potentials of the light-driven responses for different spot sizes. Figure $3 A$ shows the light responses of a ganglion cell for spots of increasing diameters $(50,200$, and $1000 \mu \mathrm{m})$ and for annular stimulation (200 $\mu \mathrm{m}$ inner diameter and $1000 \mu \mathrm{m}$ outer diameter). At a $V_{\mathrm{H}}$ of $-75 \mathrm{mV}$ and for a spot size of $50 \mu \mathrm{m}$ diameter, the cell responded with an inward current at both light $\mathrm{ON}$ and at light OFF (Fig. $3 A$, left column). This characteristic response to presentations of a small light spot is clearly different from ON (Fig. $2 A$ ) and OFF (Fig. $2 B$ ) ganglion cells and is the signature of $\mathrm{ON}-\mathrm{OFF}$ ganglion cells. The morphology of the cell is shown in Figure $1 C$ and clearly resembles a bistratified ON-OFF direction-selective ganglion cell (Amthor et al., 1989b; Vaney, 1994). Unfortunately, we did not test the cell with moving light stimuli; hence, its preferred direction is unknown. By changing the holding potential of this ON-OFF cell, we were able to plot current-voltage curves (Fig. $3 B$, peak currents; Fig. $3 C$, sustained currents) and to measure the reversal potentials of the light-evoked currents. When the cell was stimulated with a small spot, the peak of the ON response reversed near $0 \mathrm{mV}$. When the spot size was increased to 200 and $1000 \mu \mathrm{m}$, however, the reversal potential shifted to more negative values (Fig. $3 B$ ). Annular stimuli produced even more negative reversal potentials. The sustained $\mathrm{ON}$ response (Fig. $3 C$ ) showed a similar shift in reversal potential with spot size. Note, however, that the reversal potential was already negative for the $50 \mu \mathrm{m}$ spot. We interpret this negative-going shift in reversal potential with increasing spot size as a shift of the balance between inhibitory and excitatory currents. In the case of the $50 \mu \mathrm{m}$ spot, 

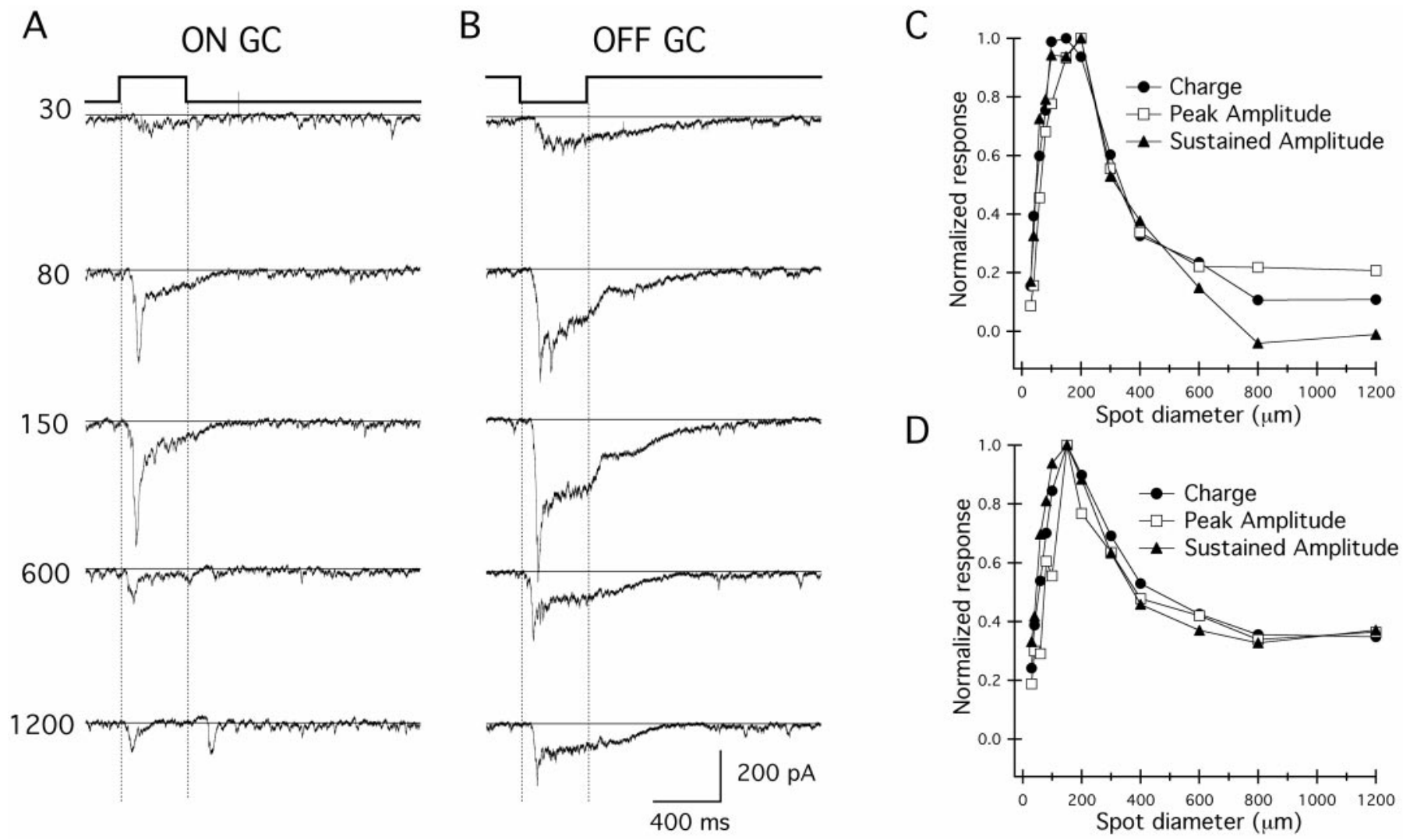

Figure 2. Light-induced currents of retinal ganglion cells voltage clamped at $V_{\mathrm{H}}$ of $-75 \mathrm{mV}$. $A$, This ON ganglion cell $(G C)$ was stimulated with different sized light spots of $400 \mathrm{msec}$ duration (top trace). Their diameters (in micrometers) are indicated on the five current traces. $B$, This OFF ganglion cell $(G C)$ was stimulated with dark spots of different sizes (diameters as in $A$ ). $C$, Area-response function of the ON ganglion cell shown in $A$. The $a b s c i s s a$ shows the diameters of the light spots, and the ordinate shows the normalized responses of the cell. The peak amplitudes of the currents, their sustained components, and the charge transfer (integral of the current over the time axis) were measured. $D$, Area-response function of the OFF ganglion cell shown in $B$.

nonselective cationic (excitatory) currents with a reversal potential close to $0 \mathrm{mV}$ preferentially contributed to the $\mathrm{ON}$ response. With increasing spot diameter, $\mathrm{Cl}^{-}$currents (inhibitory) represent a greater part of the $\mathrm{ON}$ response. At the chosen $\mathrm{Cl}^{-}$ concentration inside the recording pipette and therefore inside the ganglion cell, the $\mathrm{Cl}^{-}$reversal potential according to the Nernst equation would be between -45 and $-55 \mathrm{mV}$. The increasing proportion of the $\mathrm{Cl}^{-}$conductance ought to shift the reversal potential of light-evoked currents to more hyperpolarized potentials. This experiment suggests that direct inhibitory inputs gating $\mathrm{Cl}^{-}$conductances contribute one part of the reduction of the response of the ganglion cell to large spots. The reduction of the bipolar cell light responses attributable to lateral inhibition from horizontal and amacrine cells (indirect inhibition) contributes the other part.

One might argue that this shift in balance from excitation to inhibition is not the result of lateral inhibition but is caused by a saturation of the ganglion cell light response attributable to the large spot size. We therefore measured whether the amplitudes and reversal potentials of the light responses are spot size dependent or intensity dependent (Fig. 4). As can be seen in Figure 4A, the light responses for both the small and the large stimuli increased monotonically when the light intensity was raised by 3 $\log$ units. Hence, by choosing a light intensity for the arearesponse measurements in the middle of the intensity range, we made sure that we did not apply any saturating light spots.
Moreover, the responses for the large light spot were smaller than those for small spot at all intensities tested (Fig. 4A), indicating that lateral inhibition is primarily independent of the actual light intensity (Merwine et al., 1995). We also measured the reversal potentials of the light responses at different intensities (Fig. 4B). The reversal potential for the small spot $(100 \mu \mathrm{m})$ was close to -5 $\mathrm{mV}$ and did not shift when the light intensity was increased. The reversal potential for the large spot $(1200 \mu \mathrm{m})$ was close to -45 $\mathrm{mV}$ and also did not shift when the light intensity was increased. Such measurements were performed on a total of seven ganglion cells and show that the reversal potentials are not intensity dependent but are spot size dependent. The spot size causes the shift in balance between excitation and inhibition.

This is further corroborated in Figure 5 for an $\mathrm{ON}$ ganglion cell (same cell as Fig. $2 A$ ) that was stimulated with a light spot of $200 \mu \mathrm{m}$ diameter. The cell was voltage clamped at $V_{\mathrm{H}}$ values of 0 $\mathrm{mV}$ (the reversal potential of the cationic currents), $-55 \mathrm{mV}$ (the reversal potential of the $\mathrm{Cl}^{-}$currents), and $-75 \mathrm{mV}$. A lightdriven $\mathrm{Cl}^{-}$outward current can be detected in Figure 5 at $V_{\mathrm{H}}$ of $0 \mathrm{mV}$. At the $\mathrm{Cl}^{-}$reversal potential (Fig. $5, V_{\mathrm{H}}$ of $-55 \mathrm{mV}$ ), only excitatory currents should show up, and the response is dominated by an inward current at light ON. At the holding potential of $-75 \mathrm{mV}$, both the $\mathrm{Cl}^{-}$and the cationic currents should sum up to the inward current measured.

Comparable with Figure 2, we measured area-response functions at the $V_{\mathrm{H}}$ of $-55 \mathrm{mV}$, isolating the $\mathrm{Na}^{+} / \mathrm{K}^{+}$conductance, 

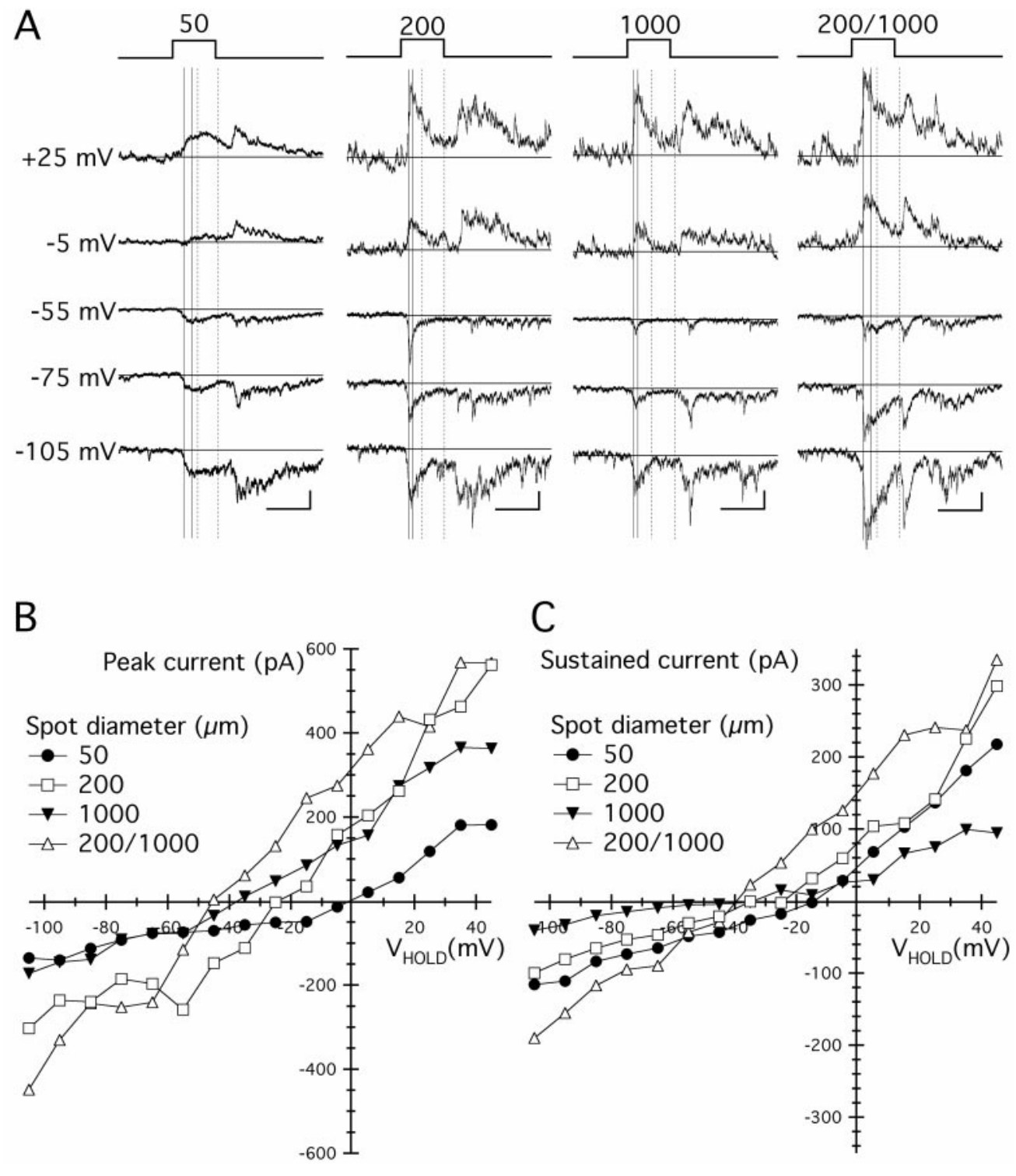

Figure 3. Reversal potentials of the light-induced currents of an $\mathrm{ON}-\mathrm{OFF}$ ganglion cell. $A$, The cell was voltage clamped at different holding potentials $\left(V_{H O L D}\right.$; shown on the left), and the light-induced currents are shown. Light spots of 50, 200, and $1000 \mu \mathrm{m}$ diameter and an annulus (inner diameter $200 \mu \mathrm{m}$, outer diameter $1000 \mu \mathrm{m}$ ) were projected into the receptive field (top trace). Calibration: $400 \mathrm{msec}, 100 \mathrm{pA}$. Peak currents were measured as the average current between the two solid lines, and sustained currents were measured as the average current between the two dotted lines. $B$, Current-voltage curves of the peak currents measured in $A$ for the different light stimuli. $C$, Current-voltage curves of the sustained currents measured in $A$ for the different light stimuli.

and $V_{\mathrm{H}}$ of $0 \mathrm{mV}$, isolating the $\mathrm{Cl}^{-}$conductance (Fig. $5 B$ ). The area-response function at $V_{\mathrm{H}}$ of $-55 \mathrm{mV}$ represents the direct excitatory input of the ganglion cell. It shows a sharp peak at a spot diameter of $200 \mu \mathrm{m}$ and is strongly reduced for larger spot diameters. This suggests that neurons providing the excitatory drive of the ganglion cell, such as bipolar cells, are themselves under the influence of a substantial lateral inhibition, possibly from horizontal cells in the OPL and/or amacrine cells in the IPL. The area-response function measured at $V_{\mathbf{H}}$ of $0 \mathrm{mV}$ represents the spatial profile of the direct inhibitory influence onto the ganglion cell. Up to a spot diameter of $400 \mu \mathrm{m}$ it shows a continuous increase, and for larger spot sizes only a moderate decrease can be observed. This suggests that the direct inhibitory input is caused by cells that have larger dendritic fields than the ganglion cell and that receive less surround inhibition.

In 87 of the recorded 105 ganglion cells, we were able to biophysically characterize the membrane currents as described above (ON cells, 42; OFF cells, 26; and ON-OFF cells, 19). Light-evoked $\mathrm{Cl}^{-}$currents were observed in 76 cells, and in 55 of 65 cells tested, we observed an increase of the $\mathrm{Cl}^{-}$currents when the diameter of the light spot was enlarged beyond the receptive field center. In 11 cells, we could record no light-evoked $\mathrm{Cl}^{-}$ current whatsoever.

The results presented in this paragraph depend critically on the quality of the space clamp of the recorded ganglion cells (Velte and Miller, 1996), and it is possible that the separation of $\mathrm{Cl}^{-}$ currents and $\mathrm{Na}^{+} / \mathrm{K}^{+}$currents is not as perfect as the holding potentials would predict. It is also possible that we actually underestimate the inhibitory currents measured for the large spots in Figure $3 B$. Such large spots open many glutamate-gated channels along the ganglion cell dendrites; at $V_{\mathrm{H}}$ of $0 \mathrm{mV}$, we do not see their currents, but they make the membrane leaky and $\mathrm{Cl}^{-}$currents are reduced. Similarly, large spots also activate inhibitory conductances along the ganglion cell dendrites; at $V_{\mathrm{H}}$ of $-55 \mathrm{mV}$ we do not see their currents, but they make the membrane leaky and excitatory currents are reduced.

\section{Light-driven responses and the internal $\mathrm{Cl}^{-}$ concentration of ganglion cells}

To further corroborate the contribution of a direct, $\mathrm{Cl}^{-}$mediated inhibition in the ganglion cell surround responses, we also recorded light-evoked action potentials from ganglion cells 
A

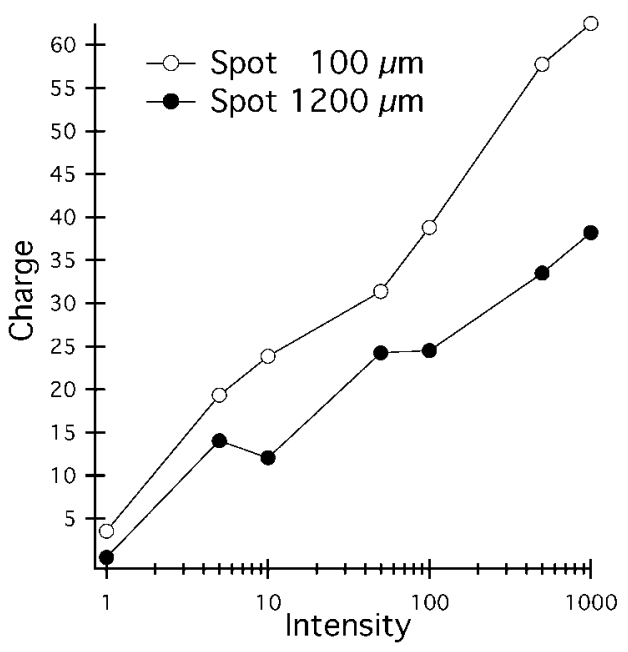

A

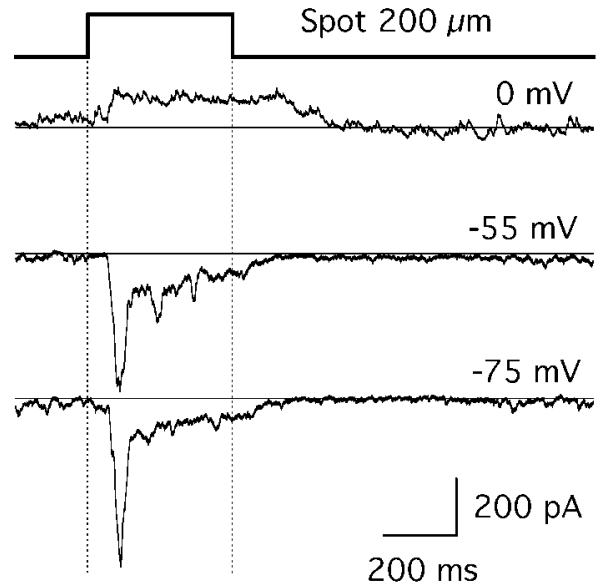

B

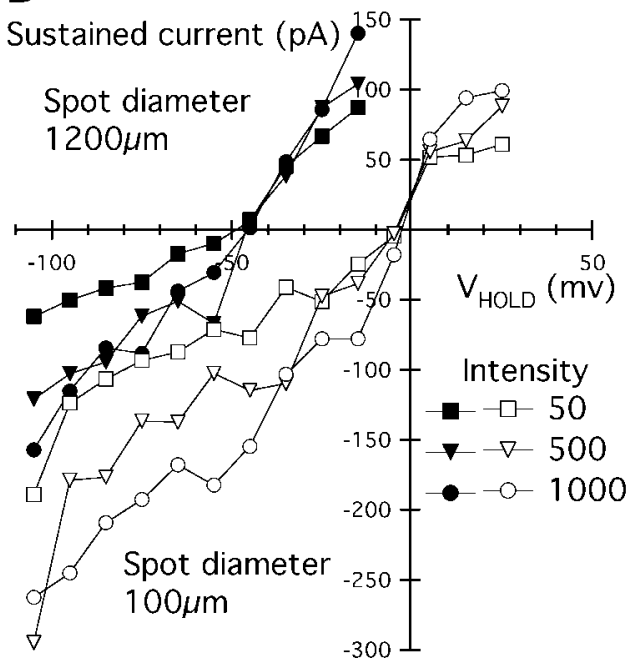

B

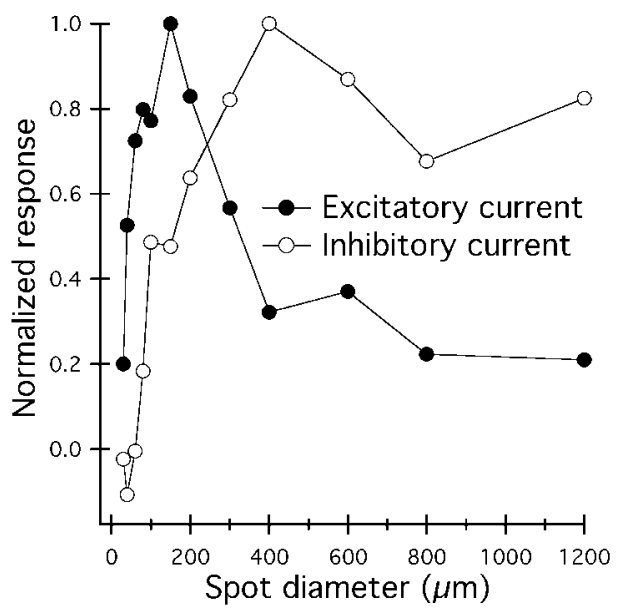

Figure 4. A, Increase of the light response of an ON center ganglion cell with increasing light intensity. The cell was voltage clamped at $V_{\mathrm{H}}$ of $-75 \mathrm{mV}$. The ordinate shows the charge transfer into the cell in picocoulombs (integral of the current over the $400 \mathrm{msec}$ of the light stimulus), and the two curves show the intensity-response functions for two spot sizes. The abscissa shows the light intensity in relative units. The intensity 1000 represents $0.7 \mathrm{~cd} / \mathrm{m}^{2}$ at the monitor. $B$, Reversal potentials of the light-induced currents of this ganglion cell for light spots of $100 \mu \mathrm{m}$ (open symbols) and $1200 \mu \mathrm{m}$ (filled symbols) diameter. The curves were measured at three different intensities, and the sustained currents are shown. The reversal potentials are independent of the light intensities.
Figure 5. A, Light-induced currents of an ON ganglion cell (same cell as Fig. $1 A$ ) that was voltage clamped at three different holding potentials. The holding potential $V_{\mathrm{H}}$ of $0 \mathrm{mV}$ represents the $\mathrm{Na}^{+} / \mathrm{K}^{+}$reversal potential, and $V_{\mathrm{H}}$ of $-55 \mathrm{mV}$ is the $\mathrm{Cl}^{-}$reversal potential. $B$, Area-response functions of the lightinduced currents in $A$, measured at $V_{\mathrm{H}}$ of $-55 \mathrm{mV}$ (excitatory current) and $V_{\mathrm{H}}$ of $0 \mathrm{mV}$ (inhibitory current). $(n=3)$ in the current-clamp mode. In a first set of recordings, we used a patch pipette with low internal $\mathrm{Cl}^{-}$solution (see Materials and Methods). The recordings were performed in the currentclamp configuration at the resting potential (Fig. 6A). The morphology of the cell was recovered (Fig. $1 A$ ), and it was an $\alpha$ ganglion cell from the center of the visual streak. The cell responded with a transient burst of spikes at light ON. When stimulated with an annulus, the cell gave a small response at light OFF. During stimulation with a large light spot, a few spikes were recorded at light $\mathrm{ON}$. Hence, lateral inhibition greatly reduces the ON response for large spots. Subsequently, the electrode was pulled off of the cell body and another patch electrode, filled with high internal $\mathrm{Cl}^{-}$solution $\left(\mathrm{E}_{\mathrm{Cl}} \cong 0 \mathrm{mV}\right)$, was used to record from the same cell once more. When we repatched the cell, we could observe a gradual increase of the maintained discharge rate (Fig. $6 B$ ) while the cell was dialyzed with the high $\mathrm{Cl}^{-}$concentration. This gradual increase convinced us that it was not injury that depolarized the cell. The light response with high internal $\mathrm{Cl}^{-}$ solution for the small spot was more vigorous (Fig. 6B), and stimulation with the annulus elicited a response at both light OFF and, in contrast to Figure $6 A$, also light ON. Finally, and most importantly, the light response for the large spot was greatly increased over low internal $\mathrm{Cl}^{-}$solution and nearly matched the response for the small spot with high internal $\mathrm{Cl}^{-}$solution. The most parsimonious explanation for this increase of the discharge rate and the removal of surround inhibition is that it is caused by the high $\mathrm{Cl}^{-}$concentration in the pipette and inside the recorded ganglion cell. Because the resting potential of the cell is more negative than the $\mathrm{Cl}^{-}$reversal potential, openings of GABA- and glycine-gated $\mathrm{Cl}^{-}$channels cause an efflux of $\mathrm{Cl}^{-}$and thus a depolarization of the ganglion cell instead of the inhibition measured in Figure $6 \mathrm{~A}$.

\section{Pharmacological characterization of the direct inhibition}

Ganglion cell dendrites express different types of $\mathrm{GABA}_{\mathrm{A}}$ and glycine receptors in synaptic hot spots (Koulen et al., 1996). $\mathrm{GABA}_{\mathrm{C}}$ receptors were not found on ganglion cell dendrites (Feigenspan et al., 1993; Enz et al., 1996). We therefore applied the specific antagonists bicuculline and strychnine to block the inhibitory influences. However, because presynaptic neurons also express GABA and glycine receptors, we had to study the lightevoked currents of ganglion cells at the reversal potential of their excitatory inputs, close to $V_{\mathrm{H}}$ of $0 \mathrm{mV}$. Such a recording is shown 


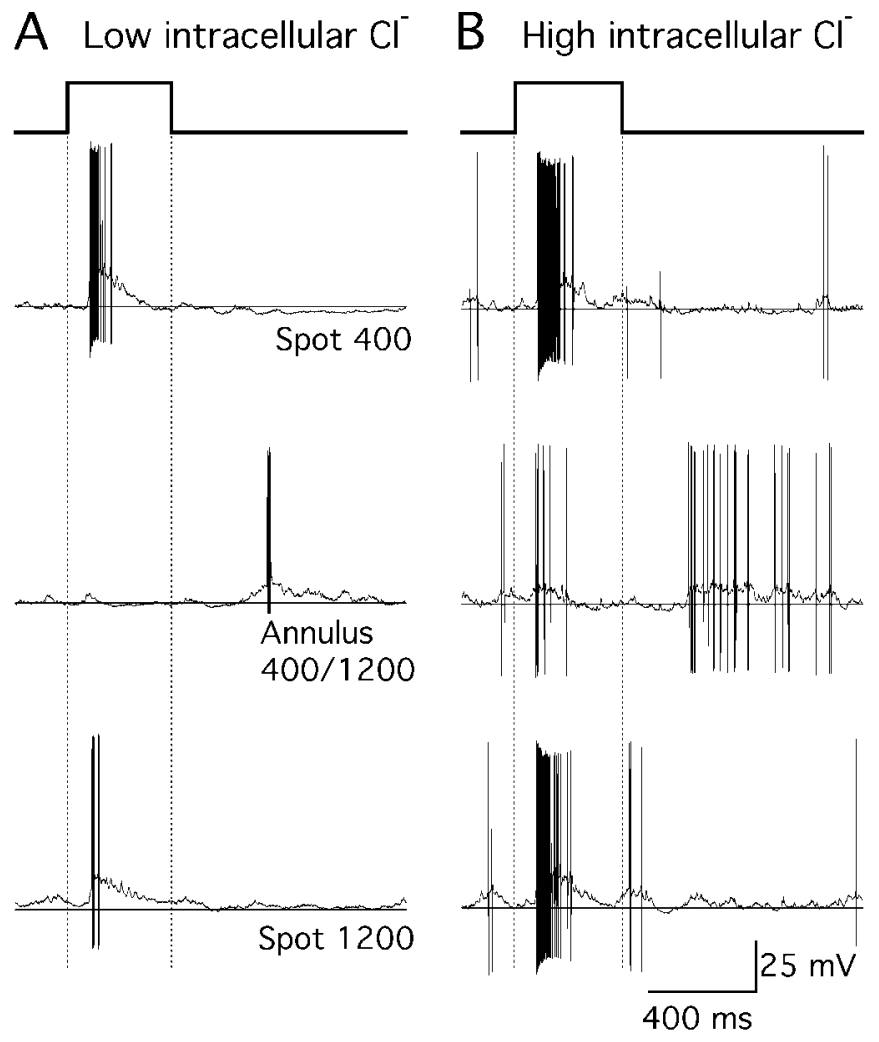

Figure 6. Light-induced action potentials of an $\mathrm{ON}$ ganglion cell recorded in the current-clamp mode. The records in $A$ were performed with an electrode containing a low $\mathrm{Cl}^{-}$concentration. The light stimuli were a spot of $400 \mu \mathrm{m}$ diameter (top trace), an annulus of inner diameter 400 $\mu \mathrm{m}$ and outer diameter $1200 \mu \mathrm{m}$ (middle), and a large spot of $1200 \mu \mathrm{m}$ diameter. The records in $B$ were taken from the same cell with an electrode containing a high $\mathrm{Cl}^{-}$concentration. Same light stimuli as in $A$ were used.

in Figure $7 A$. An annular light stimulus was chosen to maximize lateral inhibition, which occurs at both light $\mathrm{ON}$ and light OFF (Fig. 7A). Application of bicuculline and strychnine to the bathing medium strongly reduced these outward currents, suggesting that they represent GABAergic and/or glycinergic inhibition. We also studied the action of bicuculline and strychnine independently. Strychnine was applied to a total of 14 ganglion cells and reduced light-evoked $\mathrm{Cl}^{-}$currents in three of them (ON, 2; OFF, 1; and ON-OFF, 0). Bicuculline was applied to 17 ganglion cells, and the light-evoked chloride currents could be blocked in 14 cells (ON, 10; OFF, 4; and ON-OFF, 2). We also applied the GABA blocker picrotoxinin during stimulation with an annulus and clamping the ganglion cell at $V_{\mathrm{H}}$ of $0 \mathrm{mV}$ (Fig. $7 B$ ). Picrotoxinin at the chosen concentration of $100 \mu \mathrm{M}$ is a potent blocker of GABA receptors without substantially blocking glycine receptors (Handford et al., 1996; Schofield et al., 1996). As can be seen in Figure $7 B$, application of picrotoxinin completely blocked the currents evoked by the stimulation with an annulus. This blocking effect was observed in 12 of 12 cells tested (ON, 6; OFF, 3; and $\mathrm{ON}-\mathrm{OFF}, 3)$. These results suggest that lateral inhibition at the level of the ganglion cell is preferentially mediated through GABAergic amacrine cells.

In conclusion, by voltage clamping ganglion cells at the reversal potential of their excitatory input and by stimulating their receptive field with large annuli, we could unmask light-driven $\mathrm{Cl}^{-}$ outward currents. They could be strongly reduced in most cells by
A

$10 \mu \mathrm{M}$ Bicuculline+ $0.5 \mu \mathrm{M}$ Strychnine

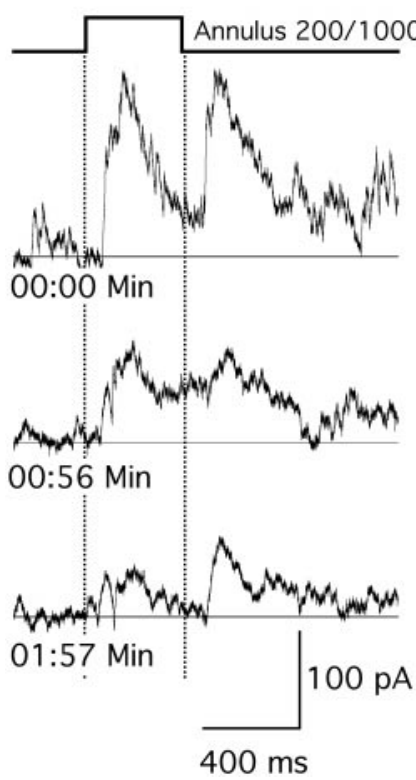

B

$100 \mu \mathrm{M}$ Picrotoxinin

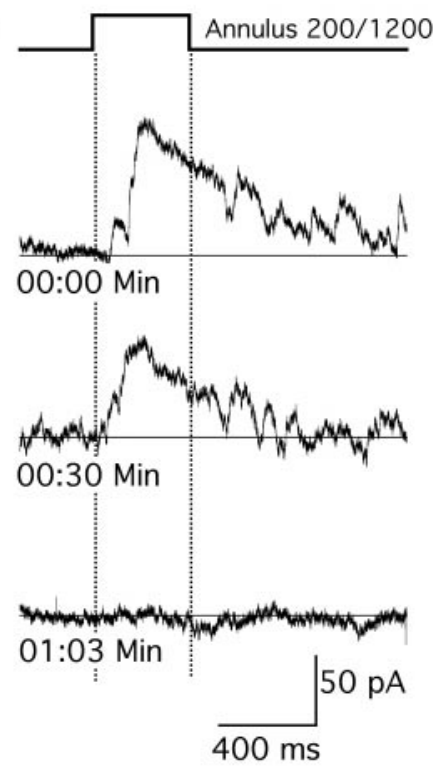

Figure 7. Light-induced currents of ganglion cells that were voltage clamped at $V_{\mathrm{H}}$ of $0 \mathrm{mV}$, the $\mathrm{Na}^{+} / \mathrm{K}^{+}$reversal potential. The cells were stimulated with an annulus. $A$, Application of bicuculline and strychnine to the bathing medium caused a substantial reduction of the outward currents recorded from this $\mathrm{ON}-\mathrm{OFF}$ ganglion cell. The time after the drug application is shown on the traces. $B$, Application of picrotoxinin to the bathing medium completely blocked the outward current of this ON ganglion cell.

the $\mathrm{GABA}_{\mathrm{A}}$ receptor antagonist bicuculline and were blocked in all cells tested by picrotoxinin. They most likely represent a direct inhibitory input from GABAergic amacrine cells onto ganglion cells.

\section{Pharmacological characterization of the "presynaptic" lateral inhibition}

There are several mechanisms and synaptic circuits through which lateral inhibition can influence the light responses of the bipolar cells, which provide the major excitatory input into ganglion cells. Bipolar cells have been shown to receive GABAergic input from amacrine cells at their axon terminals in the IPL (Pan and Lipton, 1995). Both $\mathrm{GABA}_{\mathrm{A}}$ and $\mathrm{GABA}_{\mathrm{C}}$ receptors are involved with these synapses (Fletcher et al., 1998; Koulen et al., 1998a). Bipolar cells also express glycine receptors at their axon terminals (Sassoè-Pognetto et al., 1994). In the OPL, horizontal cells can inhibit the excitatory input to bipolar cells through feedback onto the cone pedicles and by feeding forward directly onto the bipolar cell dendrites (Greferath et al., 1994; Vardi and Sterling, 1994; Haverkamp et al., 2000; Vardi et al., 2000).

In preliminary experiments, we tested various combinations of the $\mathrm{GABA}_{\mathrm{A}}$ receptor antagonist bicuculline, the $\mathrm{GABA}_{\mathrm{C}}$ receptor antagonists TPMPA (Ragozzino et al., 1996) and APMPA (Woodward et al., 1993), and the glycine receptor antagonist strychnine. However, none of them was found to successfully block all lateral inhibition. The $\mathrm{GABA}_{\mathrm{C}}$ receptor antagonists appeared to be not very specific and behaved in some cases more like GABA receptor agonist (data not shown). In contrast, we could successfully block lateral inhibition by picrotoxinin, an antagonist of both $\mathrm{GABA}_{\mathrm{A}}$ and $\mathrm{GABA}_{\mathrm{C}}$ receptors in the mam- 

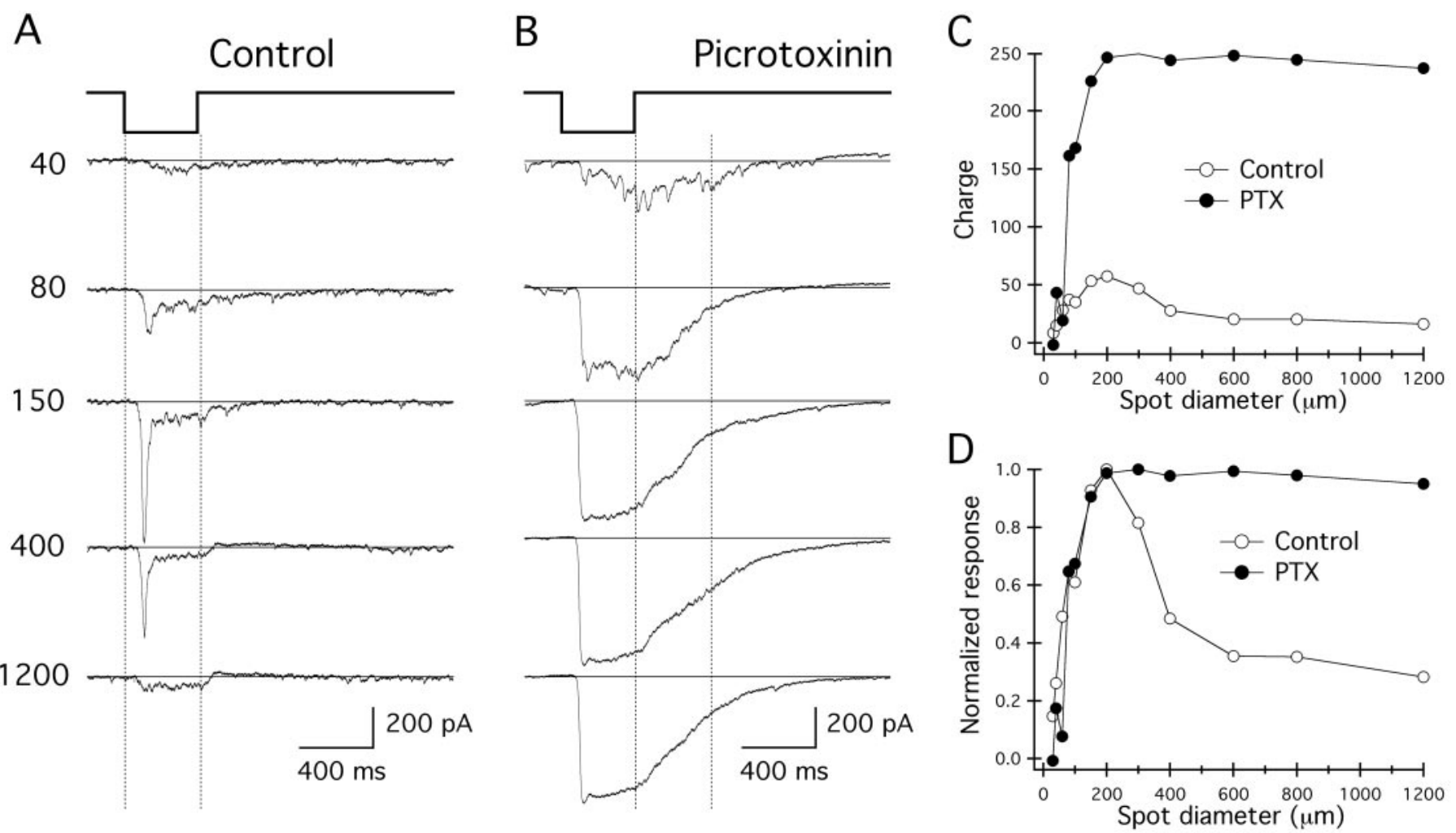

Figure 8. Light-induced currents of an OFF ganglion cell that was voltage clamped at the $\mathrm{Cl}^{-}$reversal potential $\left(V_{\mathrm{H}}\right.$ of $\left.-45 \mathrm{mV}\right) . A, \mathrm{Spots}$ of increasing diameters elicited transient inward currents that were strongly attenuated with large spots. $B$, Application of picrotoxinin (100 $\mu \mathrm{M})$ caused a substantial increase of the light-evoked currents and became more sustained, and large spots did not attenuate the currents. $C$, Area-response curves showing the charge transfer (in picocoulombs) of the currents in $A$ and $B$, respectively. $D$, Normalized area-response curves of the records in $A$ and $B$, respectively. In the control record, the large spot attenuation is apparent, and during application of picrotoxinin this attenuation appears to be primarily blocked.

malian retina (except for the rat retina; Zhang et al., 1995). Figure 8 shows recordings of the whole-cell currents of an OFF ganglion cell that was voltage clamped at $V_{\mathrm{H}}$ of $-45 \mathrm{mV}$ (the $\mathrm{Cl}^{-}$ reversal potential) to isolate the excitatory input of this ganglion cell. The morphology of this cell is shown in Figure $1 B$. It has the appearance of one type of rabbit ganglion cell, which projects to the lateral geniculate nucleus (Pu and Amthor, 1990), and of cat $\delta$ ganglion cells (Wässle and Boycott, 1991). The cell showed a transient inward current at light off (Fig. $8 \mathrm{~A}$ ), which was strongly reduced when stimulated with large light spots. This is also evident in the area-response functions shown in Figure 8, $C$ and $D$. The curve indicating the total charge flowing into the cell (Fig. $8 C$ ) and the normalized response (Fig. $8 D$ ) both peaked at a spot diameter of $200 \mu \mathrm{m}$ and decreased to $30 \%$ of the maximum for large spots. When picrotoxinin was applied (Fig. 8B), the light response of the cell showed a dramatic increase and became much more sustained. Moreover, it did not decrease when the spot size increased beyond $200 \mu \mathrm{m}$. This is shown more clearly by the area-response functions (Fig. $8 C, D$ ). As can be seen from Figure $8 C$, the total charge flowing into the cell during picrotoxinin application is five times larger than during the control condition. For spot diameters larger than $200 \mu \mathrm{m}$, no reduction can be observed. This is also documented by the normalized response shown in Figure 8D. Lateral inhibition appears to be completely abolished by the application of picrotoxinin. This was tested on 15 ganglion cells. In the control records, the light responses for large spots were reduced to an average of $33 \pm 18 \%$ of the peak response. During application of picrotoxinin, the light response for large spots was only reduced to an average of $83 \pm 12 \%$ of the peak response. In 5 of the 15 recorded cells, the response to large spots was comparable with Figure $8 D(>90 \%$ of the peak response), suggesting a near total block of all lateral inhibition. Because picrotoxinin at the concentration of $100 \mu \mathrm{M}$ is not an effective blocker of all glycinergic inhibition, it is possible that the small amount of lateral inhibition left during the application of picrotoxinin is contributed through glycinergic amacrine cells.

In conclusion, by voltage clamping ganglion cells at the $\mathrm{Cl}^{-}$ reversal potential, we could measure their excitatory input. This excitatory input was under the influence of strong lateral inhibition. Application of picrotoxinin could effectively block this inhibition, which suggests that it is mediated through GABA receptors (both $\mathrm{GABA}_{\mathrm{A}}$ and $\mathrm{GABA}_{\mathrm{C}}$ ). It has to be emphasized that GABAergic inhibition not only influences the spatial profiles of the receptive fields of ganglion cells but also strongly modulates the temporal characteristics of their light responses. The phasic light responses in Figure $8 A$ become very sustained when picrotoxinin is applied (Fig. $8 B$ ). Hence, GABAergic inhibition apparently causes this transformation from a tonic into a phasic light response.

\section{Tetrodotoxin attenuates the surround inhibition}

GABAergic amacrine cells are mostly wide field amacrine cells (Vaney, 1990; MacNeil et al., 1999; Masland and Raviola, 2000), and it has been shown that their lateral signal spread is based on voltage-gated sodium channels (Cook and McReynolds, 1998; Demb et al., 1999; Taylor, 1999). TTX has been shown in these studies to block part of the lateral inhibition mediated by the amacrine network in the IPL. However, it has not yet been shown 


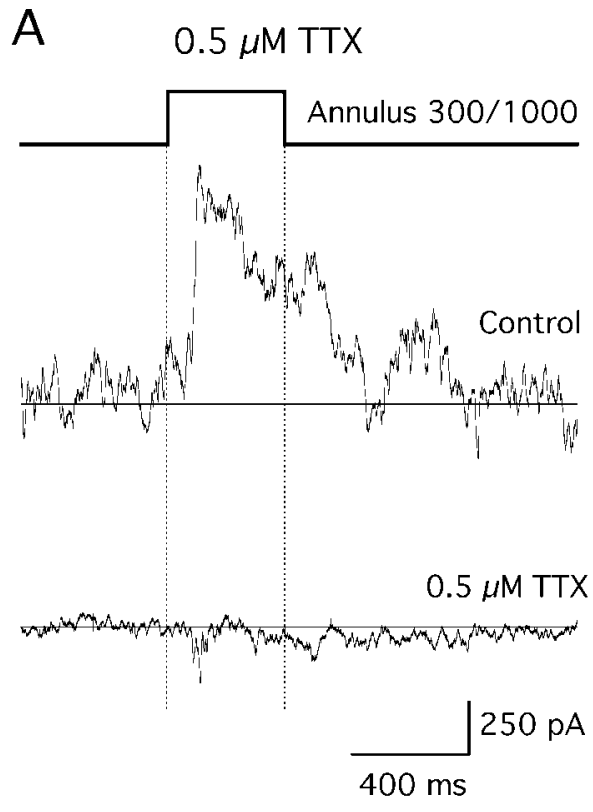

B

Figure 9. TTX application reduces lateral inhibition. $A$, Light-induced currents of an ON ganglion cell that was voltage clamped at $V_{\mathrm{H}}$ of $0 \mathrm{mV}$ and stimulated with an annulus (inner diameter $300 \mu \mathrm{m}$, outer diameter $1000 \mu \mathrm{m}$ ). The sustained outward current was blocked by the application of TTX. $B$, Area-response curves of another ON ganglion cell that was voltage clamped at $V_{\mathrm{H}}$ of $-45 \mathrm{mV}$. The light responses in the control recordings show a strong attenuation for large spots. When TTX was applied, this attenuation was substantially reduced.

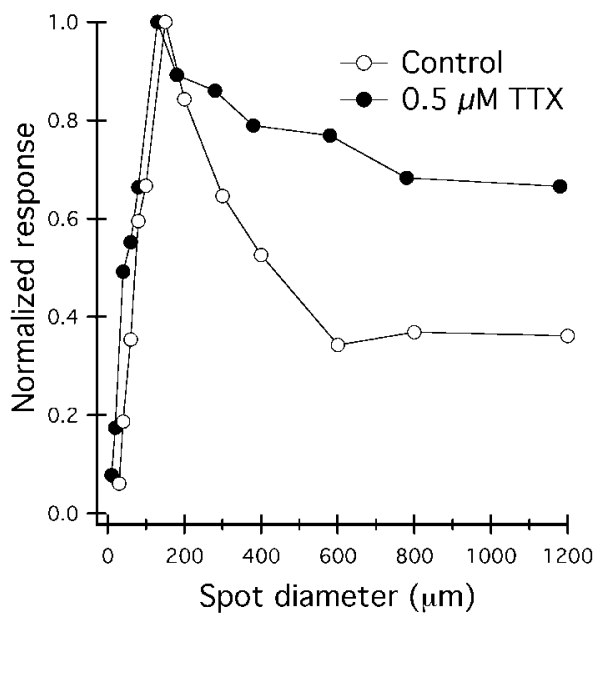

to block direct inhibition from amacrine cells onto ganglion cells. We stimulated ganglion cells with annuli and recorded the lightevoked currents at the reversal potential of the $\mathrm{Na}^{+} / \mathrm{K}^{+}$currents at $V_{\mathrm{H}}$ of $0 \mathrm{mV}$ (Fig. 9). A strong $\mathrm{ON}$ and a weaker OFF component was observed (Fig. 9A). Subsequently, we applied $0.5 \mu \mathrm{M}$ TTX to the bathing medium and found that the light-driven outward current was nearly completely blocked in 7 of 12 cells tested. This result shows that the amacrine cells mediating this direct lateral inhibition of the ganglion cell exhibit a lateral signal spread that is based on voltage-gated sodium channels.

We also studied the effect of TTX on presynaptic surround inhibition by clamping ganglion cells at $\mathrm{E}_{\mathrm{Cl}}$. Area-response functions measured without TTX (control) and during the application of TTX are shown in Figure $9 B$. The control record shows a nearly complete reduction of the light response for large spots (Fig. 9B, Control). When TTX $(0.5 \mu \mathrm{M})$ was applied to the bathing medium, the suppressive effect of large spots was greatly reduced but not completely abolished. We measured comparable area-response functions for 17 ganglion cells. In the control records, we found that large light spots reduced the ganglion cell responses to $32 \pm 20 \%$ of the peak value. When TTX was applied, this reduction was significantly attenuated to only $62 \pm 25 \%$ of the peak values. This result suggests that approximately half of the lateral inhibition is based on signal spread through voltagegated sodium channels, which is most likely contributed by spiking amacrine cells.

\section{DISCUSSION}

\section{Direct inhibitory input into ganglion cells}

In a recent, elegant study of DS ganglion cells, it has been shown by Taylor et al. (2000) that DS light responses are the result of a direct inhibitory input to ganglion cell dendrites in the IPL. This inhibitory input blocks the response of the ganglion cells in the nonpreferred direction. In the present paper, we could show that such an inhibitory input not only occurs in DS ganglion cells but appears to be a general feature of all ganglion cells. Hence, DS ganglion cells are only a special case caused by an asymmetry of the inhibition.

By voltage clamping the ganglion cells at the reversal potential of the cationic $\left(\mathrm{Na}^{+} / \mathrm{K}^{+}\right)$conductances, it became possible to study the direct inhibitory, $\mathrm{Cl}^{-}$-mediated input of the ganglion cells. However, as mentioned before, this critically depends on the quality of the space clamp (Velte and Miller, 1996). Because ganglion cells receive most of their synapses along the dendrites (Freed and Sterling, 1988; Koulen et al., 1996; Grünert, 2000; Macri et al., 2000), they must to be isopotential to fully dissect the currents. Velte and Miller (1996) have performed computer simulations of voltage clamping ganglion cells and showed that the clamp error is small for dendritic trees up to $300 \mu \mathrm{m}$ in diameter and for slow voltage changes. However, as mentioned before, large spots projected into the receptive field of the ganglion cells cause additional problems. Such large spots open channels all along the ganglion cell dendrites, which will attenuate currents arriving from the periphery of the receptive field. When isolating the direct inhibitory input of the ganglion cells, we tried to minimize this attenuation by using annular light spots (Fig. $6 A, B)$. However, in the case of the area-response functions, we certainly underestimated the direct inhibitory input.

We could show by measuring the spatial profile of the direct inhibitory input that it extends far beyond the RFC of the ganglion cells. In agreement with previous studies, we found that the RFC diameter coincides with the dendritic tree diameter of the ganglion cells (Peichl and Wässle, 1983; Amthor et al., 1984, 1989a,b; Yang and Masland, 1994). Direct inhibitory influences could be measured with annular light stimuli whose inner diameters were much larger than the ganglion cell dendritic trees or RFC diameters and with spatial summation up to a distance of 0.6 $\mathrm{mm}$ from the RFC. This suggests that amacrine cells with rather wide dendritic and receptive fields provide this input (Bloomfield, 1992; Bloomfield and Xin, 1997). However, it should be emphasized that the direct inhibitory influence was also present for small light spots projected into the RFC. This supports the model of the receptive field originally proposed by Rodieck and Stone (1965) postulating two Gaussian sensitivity profiles, a smaller one for the center mechanism and a wider one for the surround mechanism.

The direct inhibitory currents were found to depend on the $\mathrm{Cl}^{-}$concentration inside the recorded cells and were blocked in 
most ganglion cells by the application of bicuculline or picrotoxinin, suggesting they are mediated by GABAergic amacrine cells through $\mathrm{GABA}_{\mathrm{A}}$ receptors and not through $\mathrm{GABA}_{\mathrm{B}}$ receptors (Koulen et al., 1998b). Strychnine antagonized the direct inhibitory currents only in a minority of cells. This is surprising because $50 \%$ of the amacrine cells of the mammalian retina are glycinergic (Pourcho and Goebel, 1985; Wässle et al., 1986; Koontz et al., 1993). Most of them are small field amacrines (Pourcho and Goebel, 1985; MacNeil and Masland, 1998; Menger et al., 1998), and it is possible that they are more involved with local signaling. The large light spots or annuli applied in the present study to reveal inhibitory surround responses might preferentially stimulate wide field GABAergic amacrine cells.

In agreement with other reports, we found that TTX reduced the lateral inhibition in the IPL (Cook and McReynolds, 1998; Demb et al., 1999; Taylor, 1999). Some classes of amacrine cells are known to generate action potentials in rabbit retina (Bloomfield, 1992; Taylor, 1996), as well as in other vertebrate retinas (Miller and Dacheux, 1976; Barnes and Werblin, 1986; Ammermüller and Weiler, 1988; Cook and Werblin, 1994; Stafford and Dacey, 1997; Feigenspan et al., 1998), and our TTX results appear to be the consequence of the blockade of action potentials in amacrine cells.

\section{Lateral inhibition presynaptic to the ganglion cells Inner plexiform layer}

It is well established that bipolar cell axon terminals in the IPL receive many synapses from both GABAergic and glycinergic amacrine cells. Both conventional and reciprocal synapses have been observed (Chun and Wässle, 1989; Pourcho and Owczarzak, 1989, 1991a,b; Koontz and Hendrickson, 1990). At these synapses, bipolar cells express different isoforms of glycine, $\mathrm{GABA}_{\mathrm{A}}$, and $\mathrm{GABA}_{\mathrm{C}}$ receptors (Sassoè-Pognetto et al., 1994; Fletcher et al., 1998; Grünert, 2000), and the presynaptic amacrine cells represent several different morphological classes (Masland and Raviola, 2000). There is, therefore, a complex network of amacrine cells and synapses for lateral inhibition at the bipolar cell axon terminal.

Physiological recordings from dissociated bipolar cells and focal application of GABA and glycine have revealed the presence of both GABA-activated and glycine-activated $\mathrm{Cl}^{-}$currents on bipolar cell axon terminals (Karschin and Wässle, 1990; Suzuki et al., 1990; Pan and Lipton, 1995). GABA-activated $\mathrm{Cl}^{-}$currents have also been recorded from bipolar cells in retinal slices (Euler and Wässle, 1998; Lukasiewicz and Shields, 1998; Hartveit, 1999; McGillem et al., 2000). One of the experiments performed in the present study documents this inhibitory input through the bipolar cell axon terminals. We voltage clamped ganglion cells at the $\mathrm{Cl}^{-}$ reversal potential and measured the area-response functions of their excitatory input (Fig. 9B). A strong attenuation of the response was found for large stimuli. When TTX was applied, this attenuation was substantially reduced, suggesting that it is the result of inhibition from spiking amacrine cells synapsing onto the bipolar cell axon terminals. Rabbit horizontal cells have also been shown to express voltage-gated $\mathrm{Na}^{+}$channels (Löhrke and Hofmann, 1994); however, these cells are hyperpolarized by the light stimulus of Figure $9 B$. Hence, it is unlikely that they contribute to the TTX-sensitive inhibition (Taylor, 1999).

\section{Outer plexiform layer}

It has been shown recently that cones and rods of the mammalian retina express $\mathrm{GABA}_{\mathrm{A}}$ and $\mathrm{GABA}_{\mathrm{C}}$ receptors (Picaud et al.,
1998; Pattnaik et al., 2000). GABA released from horizontal cells could thus provide a negative feedback onto the photoreceptors (Murakami et al., 1982; Yazulla and Kleinschmidt, 1983; Tachibana and Kaneko, 1984; Kaneko and Tachibana, 1986; Schwartz, 1987, 1999). However, an alternative model of "electrical feedback" from horizontal cells onto cone pedicles has also been proposed (Byzov and Shura-Bura, 1986; Verweij et al., 1996; Kamermans and Spekreijse, 1999).

Immunocytochemical staining showed that bipolar cell dendrites in the OPL express $\mathrm{GABA}_{\mathrm{A}}$ receptors (Greferath et al., 1994; Vardi and Sterling, 1994) and also GABA $_{C}$ receptors (Enz et al., 1996; Haverkamp et al., 2000). Light-driven GABA release from horizontal cells (Schwartz, 1993, 1999) could be the source of lateral inhibition at the dendritic GABA receptors. There are also some GABAergic synapses from interplexiform cells onto bipolar cell dendrites (Chun and Wässle, 1989). However, for such GABAergic input into bipolar cell dendrites to represent an antagonistic light signal, one has to postulate different $\mathrm{Cl}^{-}$concentrations in the bipolar cell dendrites: a low $\mathrm{Cl}^{-}$concentration in OFF bipolar cells and a high $\mathrm{Cl}^{-}$concentration in $\mathrm{ON}$ bipolar cells. If this were be the case, then GABA released from horizontal cells would be antagonistic to both the ON and the OFF pathway. Vardi et al. (2000) have proposed recently a mechanism that could be the source of such different $\mathrm{Cl}^{-}$concentrations. They found a $\mathrm{Cl}^{-}$transporter (KCC2) (Russell, 2000) that likely extrudes $\mathrm{Cl}^{-}$in the axon terminals of $\mathrm{ON}$ and OFF bipolar cells and in the dendritic tips of OFF bipolar cells. However, in the dendrites of ON bipolar cells, they found a different transporter (NKCC) that likely accumulates $\mathrm{Cl}^{-}$in the dendritic tips.

Although the precise mechanism of lateral inhibition in the OPL still needs to be elaborated, its existence was established by an elegant experiment several years ago. Mangel (1991) injected currents into horizontal cells of the rabbit retina and observed surround responses in ganglion cells. Because horizontal cells have no connections to the inner retina, interactions in the OPL must mediate these responses.

In the present study, we could block most lateral inhibition by the application of picrotoxinin, which blocks GABA-gated and to some extent glycine-gated $\mathrm{Cl}^{-}$channels. This result suggests that the electrical feedback from horizontal cells onto cone pedicles does not contribute much to lateral inhibition in the OPL of mammals (Kamermans and Spekreijse, 1999).

\section{REFERENCES}

Ammermüller J, Weiler R (1988) Physiological and morphological characterization of OFF-center amacrine cells in the turtle retina. J Comp Neurol 273:137-148.

Amthor FR, Oyster CW, Takahashi EH (1984) Morphology of ON-OFF direction-selective ganglion cells in the rabbit retina. Brain Res 298:187-190.

Amthor FR, Takahashi ES, Oyster CW (1989a) Morphologies of rabbit retinal ganglion cells with concentric receptive fields. J Comp Neurol 280:72-96.

Amthor FR, Takahashi EH, Oyster CW (1989b) Morphologies of rabbit retinal ganglion cells with complex receptive fields. J Comp Neurol 280:97-121.

Barlow HV, Fitzhugh R, Kuffler SW (1957) Change of organization in the receptive fields of the cat's retina during dark adaptation. J Physiol (Lond) 137:338-354.

Barnes S, Werblin FS (1986) Gated currents generate single spike activity in amacrine cells of the tiger salamander retina. Proc Natl Acad Sci USA 83:1509-1512.

Bloomfield SA (1992) Relationship between receptive and dendritic field size of amacrine cells in the rabbit retina. J Neurophysiol 68:711-725.

Bloomfield SA, Xin DY (1997) A comparison of receptive-field and tracer coupling size of amacrine and ganglion cells in the rabbit retina. Vis Neurosci 14:1153-1165. 
Byzov AL, Shura-Bura TM (1986) Electrical feedback mechanism in the processing of signals in the outer plexiform layer of the retina. Vision Res 26:33-44.

Caldwell JH, Daw NW, Wyatt HJ (1978) Effects of picrotoxin and strychnine on rabbit retinal ganglion cells: lateral interactions for cells with more complex receptive fields. J Physiol (Lond) 276:277-298.

Chun MH, Wässle H (1989) GABA immunoreactivity in the cat retina: electron microscopy. J Comp Neurol 279:55-67.

Cohen ED (1998) Interaction of excitation and inhibition in the lightevoked currents of X type retinal ganglion cells. J Neurophysiol 80:2975-2990

Cook PB, McReynolds JS (1998) Lateral inhibition in the inner retina is important for spatial tuning of ganglion cells. Nat Neurosci 1:714-719.

Cook PB, Werblin FS (1994) Spike initiation and propagation in widefield transient amacrine cells of the salamander retina. J Neurosci 14:3852-3861.

Cook PB, McReynolds JS, Lukasiewicz PD (1997) GABA-mediated suppression of transient lateral inhibition in dark-adapted salamander retina. Invest Ophthalmol Vis Sci 38:5350.

Cook PB, Lukasiewicz PD, McReynolds JS (1998) Action potentials are required for the lateral transmission of glycinergic transient inhibition in the amphibian retina. J Neurosci 18:2301-2308.

Demb JB, Haarsma L, Freed MA, Sterling P (1999) Functional circuitry of the retinal ganglion cell's nonlinear receptive field. J Neurosci 19:9756-9767.

Enroth-Cugell C, Jakiela HG (1980) Suppression of cat retinal ganglion cell responses by moving patterns. J Physiol (Lond) 302:49-72.

Enroth-Cugell C, Lennie P (1975) The control of retinal ganglion cell discharge by receptive field surrounds. J Physiol (Lond) 247:551-578.

Enz R, Brandstätter JH, Wässle H, Bormann J (1996) Immunocytochemical localization of the GABAc receptor rho subunits in the mammalian retina. J Neurosci 16:4479-4490.

Euler T, Masland RH (2000) Light-evoked responses of bipolar cells in a mammalian retina. J Neurophysiol 83:1817-1829.

Euler T, Wässle H (1998) Different contributions of $\mathrm{GABA}_{\mathrm{A}}$ and $\mathrm{GABA}_{\mathrm{C}}$ receptors to rod and cone bipolar cells in a rat retinal slice preparation. J Neurophysiol 79:1384-1395.

Feigenspan A, Bormann J (1998) GABA-gated $\mathrm{Cl}^{-}$channels in the rat retina. Prog Retin Eye Res 17:99-126.

Feigenspan A, Wässle H, Bormann J (1993) Pharmacology of GABA receptor $\mathrm{Cl}^{-}$channels in rat retinal bipolar cells. Nature 361:159-162.

Feigenspan A, Gustincich S, Bean BP, Raviola E (1998) Spontaneous activity of solitary dopaminergic cells of the retina. J Neurosci 18:6776-6789.

Fletcher EL, Koulen P, Wässle H (1998) GABA $_{A}$ and $\mathrm{GABA}_{\mathrm{C}}$ receptors on mammalian rod bipolar cells. J Comp Neurol 396:351-365.

Freed MA, Nelson R (1994) Conductances evoked by light in the ON- $\beta$ ganglion cell of cat retina. Vis Neurosci 11:261-269.

Freed MA, Sterling P (1988) The ON-alpha ganglion cell of the cat retina and its presynaptic cell types. J Neurosci 8:2303-2320.

Greferath U, Grünert U, Müller F, Wässle H (1994) Localization of GABA $_{A}$ receptors in the rabbit retina. Cell Tissue Res 276:295-307.

Grünert U (2000) Distribution of GABA and glycine receptors on bipolar and ganglion cells in the mammalian retina. Microsc Res Tech 50:130-140.

Handford CA, Lynch JW, Baker E, Webb GC, Ford JH, Sutherland GR, Schofield PR (1996) The human glycine receptor $\beta$ subunit: primary structure, functional characterisation and chromosomallocalisation of the human and murine genes. Mol Brain Res 35:211-219.

Hartveit E (1999) Reciprocal synaptic interactions between rod bipolar cells and amacrine cells in the rat retina. J Neurophysiol 81:2923-2936.

Haverkamp S, Grünert U, Wässle H (2000) The cone pedicle, a complex synapse in the retina. Neuron 27:85-95.

Hurvich LM, Jameson D (1966) The perception of brightness and darkness. Boston: Allyn and Bacon.

Kamermans M, Spekreijse H (1999) The feedback pathway from horizontal cells to cones. Vision Res 39:2449-2468.

Kaneko A, Tachibana M (1986) Effects of $\gamma$-aminobutyric acid on isolated cone photoreceptors of the turtle retina. J Physiol (Lond) 73:443-461.

Karschin A, Wässle H (1990) Voltage- and transmitter-gated currents in isolated rod bipolar cells of rat retina. J Neurophysiol 63:860-876.

Koontz MA, Hendrickson AE (1990) Distribution of GABA immunoreactivity amacrine cell synapses in the inner plexiform layer of macaque monkey retina. Vis Neurosci 5:17-28.

Koontz MA, Hendrickson LE, Brace ST, Hendrickson AE (1993) Immunocytochemical localization of GABA and glycine in amacrine and displaced amacrine cells of macaque monkey retina. Vision Res 33:2617-2628.

Koulen P, Sassoè-Pognetto M, Grünert U, Wässle H (1996) Selective clustering of $\mathrm{GABA}_{\mathrm{A}}$ and glycine receptors in the mammalian retina. J Neurosci 16:2127-2140.

Koulen P, Brandstätter JH, Enz R, Bormann J, Wässle H (1998a) Synaptic clustering of $\mathrm{GABA}_{\mathrm{C}}$ receptors $\rho$ subunits in the rat retina. Eur J Neurosci 10:115-127.
Koulen P, Malitschek B, Kuhn R, Bettler B, Wässle H, Brandstätter JH (1998b) Presynaptic and postsynaptic localization of GABA $_{B}$ receptors in neurons of the rat retina. Eur J Neurosci 20:1446-1456.

Kuffler SW (1953) Discharge patterns and functional organization of mammalian retina. J Neurophysiol 16:37-68.

Löhrke S, Hofmann HD (1994) Voltage-gated currents of rabbit A- and B-type horizontal cells in retinal monolayer cultures. Vis Neurosci $11: 369-378$

Lukasiewicz PD, Shields CR (1998) Different combinations of GABA and $\mathrm{GABA}_{\mathrm{C}}$ receptors confer distinct temporal properties to retinal synaptic responses. J Neurophysiol 79:3157-3167.

Lukasiewicz PD, Wong RO (1997) GABA $_{C}$ receptors on ferret retinal bipolar cells: a diversity of subtypes in mammals? Vis Neurosci 14:989-994.

MacNeil MA, Masland RH (1998) Extreme diversity among amacrine cells: implications for function. Neuron 20:971-982.

MacNeil MA, Heussy JK, Dacheux RF, Raviola E, Masland RH (1999) The shapes and numbers of amacrine cells: matching of photofilled with Golgi-stained cells in the rabbit retina and comparison with other mammalian species J Comp Neurol 413:305-326.

Macri J, Martin PR, Grünert U (2000) Distribution of the $\alpha 1$ subunit of the $\mathrm{GABA}_{\mathrm{A}}$ receptor on midget and parasol ganglion cells in the retina of the common marmoset Callithrix jacchus. Vis Neurosci 17:437-448.

Mangel SC (1991) Analysis of the horizontal cell contribution to the receptive field surround of ganglion cells in the rabbit retina. J Physiol (Lond) 442:211-234.

Mangel SC, Miller RF (1987) Horizontal cells contribute to the receptive field surround of ganglion cells in the rabbit retina. Brain Res 414:182-186.

Masland RH, Raviola E (2000) Confronting complexity: strategies for understanding the microcircuitry of the retina. Annu Rev Neurosci 23:249-284.

McGillem GS, Rotolo TC, Dacheux RF (2000) GABA responses of rod bipolar cells in rabbit retinal slices. Vis Neurosci 17:381-389.

Menger N, Pow DV, Wässle H (1998) Glycinergic amacrine cells of the rat retina. J Comp Neurol 401:34-46.

Merwine DK, Amthor FR, Grzywacz NM (1995) Interaction between center and surround in rabbit retinal ganglion-cells. J Neurophysiol 73:1547-1567.

Miller RF, Dacheux RF (1976) Synaptic organization and the ionic basis of on- and off-channels in the mudpuppy retina. I. Intracellular analysis of chloride-sensitive electrogenic properties of receptors, horizontal cells, bipolar cells, and amacrine cells. J Gen Physiol 67:639-659.

Murakami M, Shimoda Y, Nakatani K, Miyachi E-I, Watanabe S-I (1982) GABA-mediated negative feedback from horizontal cells to cones in carp retina. Jpn J Physiol 32:911-926.

Neher E (1992) Correction for liquid junction potentials in patch clamp experiments. Methods Enzymol 207:123-131.

Pan ZH, Lipton SA (1995) Multiple GABA receptor subtypes mediate inhibition of calcium influx at rat retinal bipolar cell terminals. J Neurosci 15:2668-2679.

Pattnaik B, Jellali A, Dreyfus H, Sahel J, Picaud S (2000) GABA receptors are localized with microtubule-associated protein $1 \mathrm{~B}$ in mammalian cone photoreceptors. J Neurosci 20:6789-6796.

Peichl L, Wässle H (1983) The structural correlate of the receptive field centre of $\alpha$ ganglion cells in the cat retina. J Physiol (Lond) 341:309-324.

Peichl L, Buhl EH, Boycott BB (1987) Alpha-ganglion cells in the rabbit retina. J Comp Neurol 263:25-41.

Peters BN, Masland RH (1996) Responses to light of starburst amacrine cells. J Neurophysiol 75:469-480.

Picaud S, Pattnaik B, Hicks D, Forster V, Fontaine V, Sahel J, Dreyfus H (1998) GABA $_{\triangle}$ and $\mathrm{GABA}_{\mathrm{C}}$ receptors in adult porcine cones; evidence from a photoreceptor/glia co-culture model. J Physiol (Lond) 513:33-42.

Piccolino M (1995) Cross-talk between cones and horizontal cells through the feedback circuit. In: Neurobiology and clinical aspects of the outer retina (Djamgoz MBA, Archer SN, Vallerga S, eds), pp 221-248. Oxford: Chapman \& Hall.

Pourcho RG, Goebel DJ (1985) A combined Golgi and autoradiographic study of $\left[\mathrm{H}^{3}\right]$ glycine-accumulating amacrine cells in the cat retina. J Comp Neurol 233:473-480.

Pourcho RG, Owczarzak MT (1989) Distribution of GABA immunoreactivity in the cat retina: a light- and electron-microscopic study. Vis Neurosci 2:425-435.

Pourcho RG, Owczarzak MT (1991a) Connectivity of glycine immunoreactive amacrine cells in the cat retina. J Comp Neurol 307:549-561.

Pourcho RG, Owczarzak MT (1991b) Glycine receptor immunoreactivity is localized at amacrine synapses in cat retina. Vis Neurosci 7:611-618.

Protti DA, Llano I (1998) Calcium currents and calcium signaling in rod bipolar cells of rat retinal slices. J Neurosci 18:3715-3724.

Protti DA, Gerschenfeld HM, Llano I (1997) GABAergic and glycinergic IPSCs in ganglion cells of rat retinal slices. J Neurosci 17:6075-6085. 
Pu M, Amthor FR (1990) Dendritic morphologies of retinal ganglion cells projecting to the lateral geniculate nucleus in the rabbit. J Comp Neurol 302:675-693.

Ragozzino D, Woodward RM, Murata Y, Eusebi F, Overman LE, Miledi $\mathrm{R}$ (1996) Design and in vitro pharmacology of a selective gammaaminobutyrid acid(c) receptor antagonist. Mol Pharmacol 50:1024-1030.

Rodieck RW, Stone J (1965) Analysis of receptive fields of cat retinal ganglion cells. J Neurophysiol 28:833-849.

Rörig B, Grantyn R (1993) Glutamatergic and GABAergic synaptic currents in ganglion cells from isolated retinae of pigmented rats during postnatal development. Dev Brain Res 74:98-110.

Roska B, Werblin FS (2001) Vertical interactions across ten parallel, stacked representations in the mammalian retina. Nature 410:583-587.

Roska B, Nemeth E, Orzo L, Werblin FS (2000) Three levels of lateral inhibition: a space-time study of the retina of the tiger salamander. J Neurosci 20:1941-1951.

Russell JM (2000) Sodium-potassium-chloride cotransport. Physiol Rev $80: 211-276$.

Sassoè-Pognetto M, Wässle H, Grünert U (1994) Glycinergic synapses in the rod pathway of the rat retina: cone bipolar cells express the $\alpha 1$ subunit of the glycine receptor. J Neurosci 14:5131-5146.

Schofield PR, Lynch JW, Rajendra S, Pierce KD, Handford CA, Barry $\mathrm{PH}$ (1996) Molecular and genetic insights into ligand binding and signal transduction at the inhibitory glycine receptor. Cold Spring Harbor Symp Quant Biol 61:333-342.

Schwartz EA (1987) Depolarization without calcium can release gamma-aminobutyric acid from a retinal neuron. Science 238:350-355.

Schwartz EA (1999) A transporter mediates the release of GABA from horizontal cells. In: The retinal basis of vision (Toyoda JI, Murakami M, Kaneko A, Saito T, eds), pp 93-101. New York: Elsevier.

Stafford DK, Dacey D (1997) Physiology of the A1 amacrine: a spiking, axon-bearing interneuron of the macaque monkey retina. Vis Neurosci 14:507-522.

Sterling P, Smith RG, Rao R, Vardi N (1995) Functional architecture of mammalian outer retina and bipolar cells. In: Neurobiology and clinical aspects of the outer retina (Djamgoz MBA, Archer SN, Vallerga S, eds), pp 325-348. Oxford: Chapman \& Hall.

Suzuki S, Tachibana M, Kaneko A (1990) Effects of glycine and GABA on isolated bipolar cells of the mouse retina. J Physiol (Lond) 421:645-662.

Tachibana M, Kaneko A (1984) $\gamma$-Aminobutyric acid acts at axon terminals of turtle photoreceptors: difference in sensitivity among cell types. Proc Natl Acad Sci USA 81:7961-7964.

Taylor WR (1996) Response properties of long-range axon-bearing amacrine cells in the dark-adapted rabbit retina. Vis Neurosci 13:599-604.

Taylor WR (1999) TTX attenuates surround inhibition in rabbit retinal ganglion cells. Vis Neurosci 16:285-290.

Taylor WR, Wässle H (1995) Receptive field properties of starburst cholinergic amacrine cells in the rabbit retina. Eur $\mathrm{J}$ Neurosci 7:2308-2321.

Taylor WR, He SY, Levick WR, Vaney DI (2000) Dendritic computation of direction selectivity by retinal ganglion cells. Science 289:2347-2350.

Vaney DI (1990) The mosaic of amacrine cells in the mammalian retina. In: Progress in retinal research (Osborne N, Chader J, eds), pp 49-100. Oxford: Pergamon.

Vaney DI (1992) Photochromic intensification of diaminobenzidine reaction product in the presence of tetrazolium salts: applications for intracellular labelling and immunohistochemistry. J Neurosci Methods 44:217-223.

Vaney DI (1994) Territorial organization of direction-selective ganglion cells in rabbit retina. J Neurosci 14:6301-6316.

Vardi N, Sterling P (1994) Subcellular localization of GABA $_{\mathrm{A}}$ receptor on bipolar cells in macaque and human retina. Vision Res 34:1235-1246.

Vardi N, Zhang L-L, Payne JA, Sterling P (2000) Evidence that different cation chloride cotransporters in retinal neurons allow opposite responses to GABA. J Neurosci 20:7657-7663.

Velte TJ, Miller RF (1996) Computer simulations of voltage clamping retinal ganglion cells through whole-cell electrodes in the soma. J Neurophysiol 75:2129-2143.

Verweij J, Kamermans M, Spekreijse H (1996) Horizontal cells feed back to cones by shifting the cone calcium-current activation range. Vision Res 36:3943-3953.

Wässle H, Boycott BB (1991) Functional architecture of the mammalian retina. Physiol Rev 71:447-480.

Wässle H, Schäfer-Trenkler I, Voigt T (1986) Analysis of a glycinergic inhibitory pathway in the cat retina. J Neurosci 6:594-604.

Wässle H, Koulen P, Brandstätter JH, Fletcher EL, Becker C-M (1998) Glycine and GABA receptors in the mammalian retina. Vision Res 38:1411-1430.

Werblin F (1991) Synaptic connections, receptive fields, and patterns of activity in the tiger salamander retina. A simulation of patterns of activity formed at each cellular level from photoreceptors to ganglion cells. Invest Ophthalmol Vis Sci 32:459-483.

Woodward RM, Polenzani L, Miledi R (1993) Characterization of bicuculline/baclofen-insensitive (rho-like) gamma-aminobutyric acid receptors expressed in Xenopus oocytes. II. Pharmacology of gammaaminobutyric acid $\mathrm{A}$ and gamma-aminobutyric $\operatorname{acid}_{\mathrm{B}}$ receptor agonists and antagonists. Mol Pharmacol 43:609-625.

Yang G, Masland RH (1994) Receptive fields and dendritic structure of directionally selective retinal ganglion cells. J Neurosci 14:5267-5280.

Yazulla S, Kleinschmidt J (1983) Carrier mediated release of GABA from retinal horizontal cells. Brain Res 263:63-75.

Zhang D, Pan Z-H, Zhang X, Brideau AD, Lipton SA (1995) Cloning of a $\gamma$-aminobutyric acid type $C$ receptor subunit in rat retina with a methionine residue critical for picrotoxinin channel block. Proc Natl Acad Sci USA 92:11756-11760. 